\title{
Sir Hans Sloane (1660-1753) and the value of breast milk
}

\author{
P M Dunn
}

Hans Sloane was one of the most eminent physicians, naturalists, and collectors of his day. ${ }^{1}$ He was born on 16 April 1660 in Killyleagh, Co Down, one of the sons of Alexander Sloane, a tax collector of Scottish extraction. After attending the local school, he studied medicine in London, completing his training in France (Paris and Montpellier), and receiving his MD from the University of Orange in 1683. On returning to London, he lodged with the famous Dr Thomas Sydenham. Sloane was elected a fellow of the Royal Society in 1685 and of the Royal College of Physicians in 1687. He then spent 15 months in Jamaica as personal physician to the Governor. While there, he satisfied his interest in botany, collecting some 800 plants that were then unknown in Europe. Later he assembled his dried specimens and crayon drawings into a collection that served as the basis of a magnificent two volume work.

Returning to England in 1689, Sloane settled in Bloomsbury and rapidly established

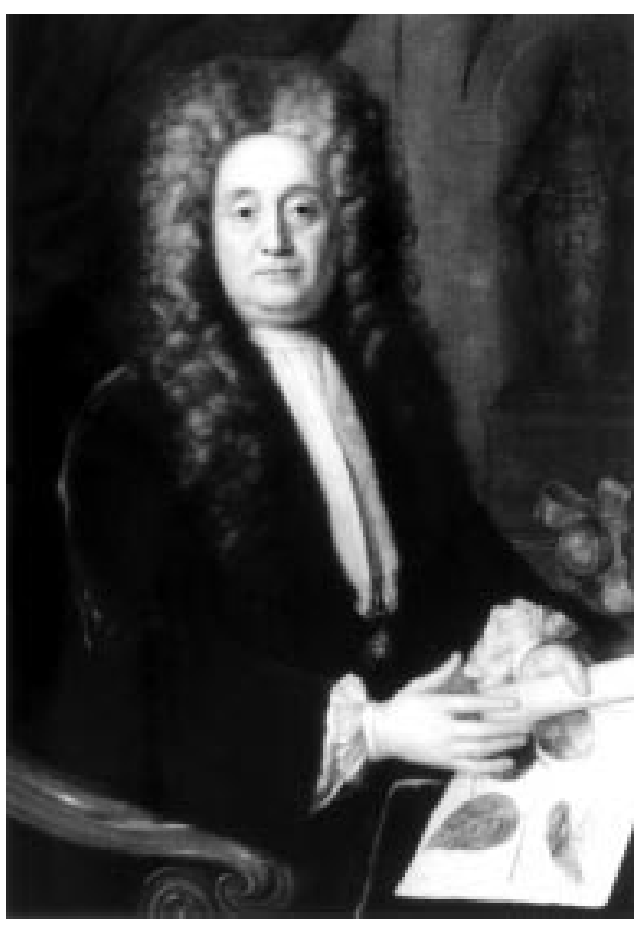

Figure 1 Sir Hans Sloane, 1660-1753 (courtesy of the National Portrait Gallery, London). himself as a leading fashionable doctor. In 1694, he was appointed physician to Christ's Hospital, a post he held for the next 34 years. In 1695 he married a wealthy widow, Mrs Elizabeth Rose, by whom he had a son who died young, and two daughters. By now a millionaire, he was able to indulge his passion for natural history and collecting. At the same time, he had risen to the head of his profession. In 1701 he attended Queen Anne, in 1716 was created a baronet by George I (the first doctor to be so honoured), and in 1727 became physician to George II. The academies of Paris, Petersburg, and Madrid also honoured him. Between 1719 and 1735, he was President of the Royal College of Physicians and, after Sir Isaac Newton's death in 1727, was elected President of the Royal Society, an appointment he retained until his retirement in 1741 (fig 1).

Sir Hans Sloane was a foundation Governor to Captain Coram's Foundling Hospital, opened in Bloomsbury in 1741. Seven years later in 1748 at the age of 88 he wrote to the Vice President of the hospital a letter ${ }^{2}$ on the nursing of infants that reveals his exceptional common sense and intelligence. This letter, from which the following extracts are taken, deserves to stand alongside the famous pamphlet of Dr William Cadogan ${ }^{3}$ on the same subject, which had also been addressed to the Foundling Hospital earlier that year.

\section{On the nursing of infants}

“. . . infants, which by the management of parish nurses, in giving them diacodium, or other opiats, to quiet them when fretting with diseases occasioned by their bad nourishment, generally sweet'ned with sugar, and the want of the breast by wett nurses, scarse ever live to two years old . . . My opinion I told you, and the rest of the Governors, was founded on the experience that I had for fifty years, that as far as my memory served me, I observed that in three infants bred without breasts, two generally dyed, or in that proportion, notwithstanding what I or others could do to help them. This, I generally thought, proceeded from deviating from the orders of God and nature, to follow men's inventions. I have allways immediately advised, in such cases, the breast, as the first and best remedy, which seldom fails, unless 
the child would not suck, in which case, breast-milk given with a spoon is the best remedy ... What deceives unthinking people is, the children taking down such artificiall succedaneous nourishment or victuals with seeming complacency: they do not consider that any infant will swallow even any poyson, that hath no ill tast, that is putt into its mouth.

The bad qualities of many wett nurses, and their opinion of being so necessary to families, hath sometimes made their masters weary of such servants, and obliged them to try what they did not so well consider or know. They did not know that . . .a disproportion'd nourishment might occasion great disorders, not only in the primae viae, but also in the turnings, and many circumvolutions in the gutts and several glands of the body, which might occasion rickets and the king's evil, and these sort of diseases, more taken notice of in England than other countries. The infant's incapacity of judging, must by the order of nature and Providence, devolve to the parents, and seems to be pointed out for sucking, till they have teeth to tear or grind. I have seen and very much condemn'd the custom of some who, too soon, put into the hands of infants dry crusts of bread, chickens' leggs, and other obstructing nourishment; and I have seen the liveliest and healthiest children, who never had other nourishment than from the breast for upwards of one, if not two years. This too thick nourishment, in elder people, is helped by drinking, when prompt to it by thirst, or oppression at their stomach, which children are not able to discover.

The natural and customary time of the appearance of teeth is about eight months, if pregnancy happens, then a dry very carefull nurse may suffice, and the child wean'd; if before, a wett nurse must be procured. I think the difference of the age of a wett nurse's milk is not to be so much regarded, having in my own family had one wett nurse suckle four children successively, who have been and now are healthy and well.

The mischiefs that arise from want of breastmilk are gripes, from the disproportion'd food turning generally soure, giving green stools, causing pain, and irritating the gutts to discharge them ... When loosenesses and green stools happen to infants, testaceous powders, as chalk, crabs eyes, claws, etc., helps more than rhubarb, which purges them more, and is no way to be depended on for strengthening the bowells ...

Another thing I have taken notice of as a great fault in the management of infants, is the putting them too soon upon their leggs, and bribing them to walk alone, or even with the help of leading-strings, which brings many crooked bones, from their not having acquired a suitable hardness to sustain, but grow crooked under the weight of their bodies, nature rather seeming to design their grovelling on their hands and feet at first, than standing erect. Most other nations have their limbs streight for that reason; and I do not remember to have seen, in whole countrys, for some years, so many crooked bones as are to be seen in half an houres passing the streets in London, not counting such as are bed-rid, confined at home, or women whose habits hide their deformities of that kind.

If you remember, at that time, it pleased God, I fell very ill, and was not able to attend you at the meeting of the Guardians of the Foundling Hospital, who were advised to bring up by hand all such infants as would feed, and suckle only such as would not. This being much against my opinion, from the ill effects I had observed by it (as I had before told you and the rest of the Governors), made me some time after, upon my recovery, inquisitive about the event of it; when, upon examining the books of the Hospital, I found as follows, by which it plainly appears, that what I said was agreable to matter of fact:

March 25th, 1741 - admitted 30 children; to wett nurses, 2: dyed, -: to dry nurses, 28; dyed, 15.

April 17th, 1741 - admitted 30 children; to wett nurses, 7; dyed, 1: to dry nurses, 22; dyed, 11 .

May 8th, 1741 - admitted 30 children; to wett nurses, 17; dyed, 4: to dry nurses, 13; dyed 8.

Total children admitted, 90. Total to wett nurses, 26; dyed 5. Total to dry nurses, 63; dyed, 34. Taken out, 1."

From the above figures, it can be seen that the mortality for infants who were dry nursed was nearly three times greater than that for those who were wet nursed ( $54 \%$ v 19\%), a highly significant difference. Although retrospective and non-randomised, this observation must be one of the earliest, if not the earliest, to use audit and statistics to guide medical practice.

In 1712 Sir Hans Sloane had purchased the Manor of Chelsea, and nine years later created his Botanic Gardens. They were visited by Carl Linnaeus in 1736. Eventually Sloane gave their freehold to the Company of Apothecaries, who in gratitude erected a statue of him there. Meanwhile, his library and collection of pictures, coins, and curiosities had grown to some 200000 items. In his will, he bequeathed them to the nation on condition that parliament paid his executors $£ 20000$. His offer was accepted and the collection opened to the public as the British Museum in 1759. Sir Hans Sloane died aged 93 on 11 January 1753 and was buried in Chelsea churchyard. His memory has been perpetuated in a number of London place names, the best known of which is Sloane Square.

1 Palmer JB. Sir Hans Sloane. New Ulster, Spring 1992.

2 Sloane $\mathrm{H}$. The nursing of children. Letter to John Milner Esq, 28th October 1748. In: Brownslow J, ed. Memoranda or Chronicles of the Foundling Hospital including Memoirs of
or Captain Coram. London: Sampson Low, 1847:210-16.

Captain Coram. London: Sampson Low, 1847:210-16.
3 Dunn PM. Dr William Cadogan (1711-1797) and the management of infants. Arch Dis Child 1992;67:72-3. 